\title{
Cannabis Abuse and Hematological Variations to Endorse Severe Health Implications Among Kashmiri Youth
}

\author{
Irfan Ahmad Wani*1, Bhupinder Singh ${ }^{2}$ and Muzafer Ahmad Khan ${ }^{3}$ \\ ${ }^{1}$ Research Scholar utd, Barkatullah University Bhopal M.P, India \\ ${ }^{2}$ Professor utd, Barkatullah University Bhopal M.P, India \\ ${ }^{3}$ Director Drug De-Addiction and Rehabilitation Centre Police Control Srinagar Kashmir, India
}

Submission: July 13, 2018; Published: July 19, 2018

*Corresponding author: Irfan Ahmad Wani, Research Scholar utd Barkatullah University Bhopal M.P India, Tel: 917006558529; Email: wanipsy@ gmail.com

\begin{abstract}
The present study is conceded out to scrutinize the effect of cannabis abuse on blood composition of cannabis abusers in contrast with control group of Kashmiri youth by taking complete blood count test to figure out the occurrence of hematological variations which are typical cause of health pathology. The sample consisted of 300 male patients on which CBC test was taken of these 150 were belong to cannabis abusers and rest were belong to control group. The result of the study showed that two groups significantly differed on Hemoglobin, Hematocrit, RBC count, platelet count, total Leucocyte count, Neutrophils, Lymphocytes, Monocytes, Eosionophills, Basophil, absolute Neutrophil count, absolute Lymphocytes count, absolute Monocyte count, absolute Eosionophil count, absolute Basophills and glucose fasting. While in MCV, MCH, MCHC and RDW-CV contents remain non-significant among cannabis abusers.
\end{abstract}

Keywords: Cannabis abuse; Haematology; Thromboembolism and hypochromia

Abbreviations: MCV: Mean Corpuscular Volume; MCH: Mean Corpuscular Hemoglobin; MCHC: Mean Corpuscular Hemoglobin Concentration

\section{Introduction}

The most contentious use of the cannabis sativa plant is for its psychoactive properties a chemical namely Delta-9tetrahydriocannabinol (THC) Ebuehi OAT [1]. Cannabis smoke contains various chemicals, including THC, carbon monoxide and carcinogens (substances that cause cancer) (British Medical Association BMA [2]. Cannabis is consumed by various routes, with the most common route smoking Baggio et al. [3]. Inhalation by smoking or vaporization releases maximal levels of THC into blood within minutes, peaking at 15-30 minutes, and decreasing within 2-3 hours. Even with a fixed dose of THC in a cannabis cigarette, THC pharmacokinetics and effects vary as a function of the weight of a cannabis cigarette its preparation, the concentration of other cannabinoids, the rate of inhalation, depth and duration of puffs, volume inhaled, extent of breath-holding, vital capacity, escaped smoke and dose titration Azorlosa et al. [4]; Azorlosa et al. [5]. The components of cannabis smoke become more concentrated and stronger towards the end with each puff Tashkin et al. [6]. So the smoking of fewer cannabis cigarettes down to a shorter butt length could mean taking in a greater number of smoke components than smoking the same amount of cannabis in more cigarettes smoked to a longer butt length British Lung Foundation [7]. In humans smoking one or more cannabis cigarettes, THC levels in peripheral blood exceeded the range of 5 to $250 \mathrm{ng} / \mathrm{ml}$, while intravenous administration of $10 \mathrm{mg} / \mathrm{kg}$ THC resulted in a blood level of $720 \mathrm{ng} / \mathrm{ml}$ after 20 minutes Safarian et al. [8]. An extensive comparison of smoke (mainstream: smoke exhaled by a smoker and side stream: smoke generated from the end of a cigarette) generated by igniting cannabis and tobacco cigarettes, showed marked qualitative similarities in specific compounds (e.g. ammonia, carbon monoxide, hydrogen cyanide, among others), and also significant quantitative differences Moir et al. [9]. Blood cell production and release of anandamide may complicate measurement of endocannabinoids in blood. This complication arises from the observation that ex vivo blood samples have high rates of anandamide release and this may clearly confound analytical measurements Vogeser et al. [10] Cannabis smoking was identified in the determinants of myocardial infarction study as a risk factor for initiating a myocardial infarction, such that the risk was increased 4.8 -fold in the $60 \mathrm{~min}$ after its use 
Mittleman et al. [11]. The acute administration of cannabis being associated with an increased risk of myocardial infarction and the coronary artery risk developing in young adults trial Rodondi et al. [12]. Cannabis smoking is associated with cardiovascular effects including tachycardia and hypertension with orthostatic hypotension. The tachycardia clearly acts as a stressor, and smoking cannabis (when compared to placebo controls) has been shown provoke symptoms instable angina Aronow and Cassidy [13]. The present study tries to focus on whether cannabis abuse produces alterations in hematological parameters which leads to endorse health disorders among Kashmiri people.

Objective: The objective of the present study is to compare the blood test among cannabis abusers and control group to see the changes formed by cannabis abuse whether (higher or lower) in hematological indices to highlight the associated health and blood disorders.

Table 1: Depicts the Mean, SDs and t- values on (CBC) in Cannabis abusers and control group of Kashmiri youth.

\begin{tabular}{|c|c|c|c|}
\hline Complete Blood Count (CBC) & Methods & Biological Reference Range & Units \\
\hline Hemoglobin & Photometric & $13.0-17.0$ & $\mathrm{~g} / \mathrm{dl}$ \\
\hline Hematocrit & DC Detection Method & $40.0-50.0$ & $\%$ \\
\hline Rbc count & Automated & $40.0-50.0$ & $10^{\wedge} 6 / \mathrm{ul}$ \\
\hline MCV & & 83.0-101.0 & $\mathrm{Fl}$ \\
\hline $\mathrm{MCH}$ & & $7.0-32.0$ & $\mathrm{Pg}$ \\
\hline MCHC & & $31.5-34.5$ & $\mathrm{~g} / \mathrm{dl}$ \\
\hline RDW-CV & & $11.60-140$ & $\%$ \\
\hline Platelet Count & & $150-410$ & $10^{\wedge} 3 / \mathrm{Ul}$ \\
\hline Total leucocyte count & DC Detection Method & $4.0-11.0$ & $10^{\wedge} 3 / \mathrm{Ul}$ \\
\hline Neutrophils & & $40.0-80.0$ & $\%$ \\
\hline Lymphocytes & & $20.0-40.0$ & $\%$ \\
\hline Monocytes & & $2.0-10.0$ & $\%$ \\
\hline Eosionophills & & $1.0-6.0$ & $\%$ \\
\hline Basophilis & & $<2.0$ & $\%$ \\
\hline Absolute nutrophil count & MICROSCOPY & $2.00-7.00$ & $10^{\wedge} 3 / \mathrm{Ul}$ \\
\hline Absolute lymphocyte count & & $1.00-3.00$ & $10^{\wedge} 3 / \mathrm{uL}$ \\
\hline Absolute monocyte count & & $0.20-1.00$ & $10^{\wedge} 3 / \mathrm{uL}$ \\
\hline Absolute eosionophil count & & $0.02-0.50$ & $10^{\wedge} 3 / \mathrm{uL}$ \\
\hline
\end{tabular}

Table 2: depicts the Mean value of cannabis abusers and control group of Kashmiri youth on complete blood count test.

\begin{tabular}{|c|c|c|c|c|c|}
\hline \multirow{2}{*}{$\begin{array}{c}\text { Complete CBC } \\
\text { Hematological indices }\end{array}$} & \multicolumn{2}{|c|}{ Cannabis abusers } & \multicolumn{2}{|c|}{ Control group } & \multirow[b]{2}{*}{ t-value } \\
\hline & Mean & S.D & Mean & S.D & \\
\hline Hemoglobin & 14.58 & 4.89 & 18.47 & 4.53 & $3.25^{* *}$ \\
\hline Hematocrit & 43.76 & 8.15 & 47.56 & 9.01 & $2.95^{* *}$ \\
\hline RBC Count & 3.23 & 2.11 & 8.54 & 3.12 & $2.97^{* *}$ \\
\hline $\mathrm{MCV}$ & 79.41 & 11.23 & 80.67 & 12.76 & 1.87 (N.S) \\
\hline $\mathrm{MCH}$ & 31.92 & 7.76 & 30.41 & 4.44 & 1.23 (N.S) \\
\hline $\mathrm{MCHC}$ & 34.37 & 7.98 & 33.89 & 5.43 & 1.76 (N.S) \\
\hline RDW-CV & 13.33 & 4.08 & 14.16 & 4.95 & $1.43(\mathrm{~N} . \mathrm{S})$ \\
\hline
\end{tabular}


JOJ Nursing \& Health Care

\begin{tabular}{|c|c|c|c|c|c|}
\hline Platelet Count & 92.15 & 13.18 & 76.56 & 13.98 & $4.31^{* *}$ \\
\hline Total Leucocyte Count & 7.54 & 3.92 & 10.32 & 4.53 & $2.86^{* *}$ \\
\hline Neutrophils & 69.32 & 10.22 & 75.24 & 11.31 & $3.36^{* *}$ \\
\hline Lymphocytes & 13.78 & 4.32 & 19.33 & 5.37 & $2.76^{* *}$ \\
\hline Monocytes & 5.32 & 2.87 & 9.43 & 3.22 & $3.12^{* *}$ \\
\hline Eosionophills & 3.92 & 1.53 & 7.32 & 2.61 & $3.65^{* *}$ \\
\hline Basophilis & 2.77 & 1.05 & 6.43 & 1.77 & $3.83^{* *}$ \\
\hline $\begin{array}{l}\text { Absolute Nutrophil } \\
\text { Count }\end{array}$ & 5.22 & 2.07 & 8.98 & 2.93 & $2.68^{* *}$ \\
\hline $\begin{array}{l}\text { Absolute Lymphocyte } \\
\text { Count }\end{array}$ & 2.56 & 1.68 & 5.72 & 1.96 & $2.98^{* *}$ \\
\hline $\begin{array}{c}\text { Absolute Monocyte } \\
\text { Count }\end{array}$ & 2.38 & 1.36 & 6.78 & 1.36 & $3.12^{* *}$ \\
\hline $\begin{array}{l}\text { Absolute Eosionophil } \\
\text { Count }\end{array}$ & 1.17 & 0.92 & 4.77 & 1.98 & $2.76^{* *}$ \\
\hline $\begin{array}{c}\text { Absolute Basophil } \\
\text { Count }\end{array}$ & 2.03 & 1.03 & 7.01 & 2.26 & $2.88^{* *}$ \\
\hline Glucose Fasting & 76.53 & 8.22 & 59.71 & 6.77 & $3.67^{* *}$ \\
\hline
\end{tabular}

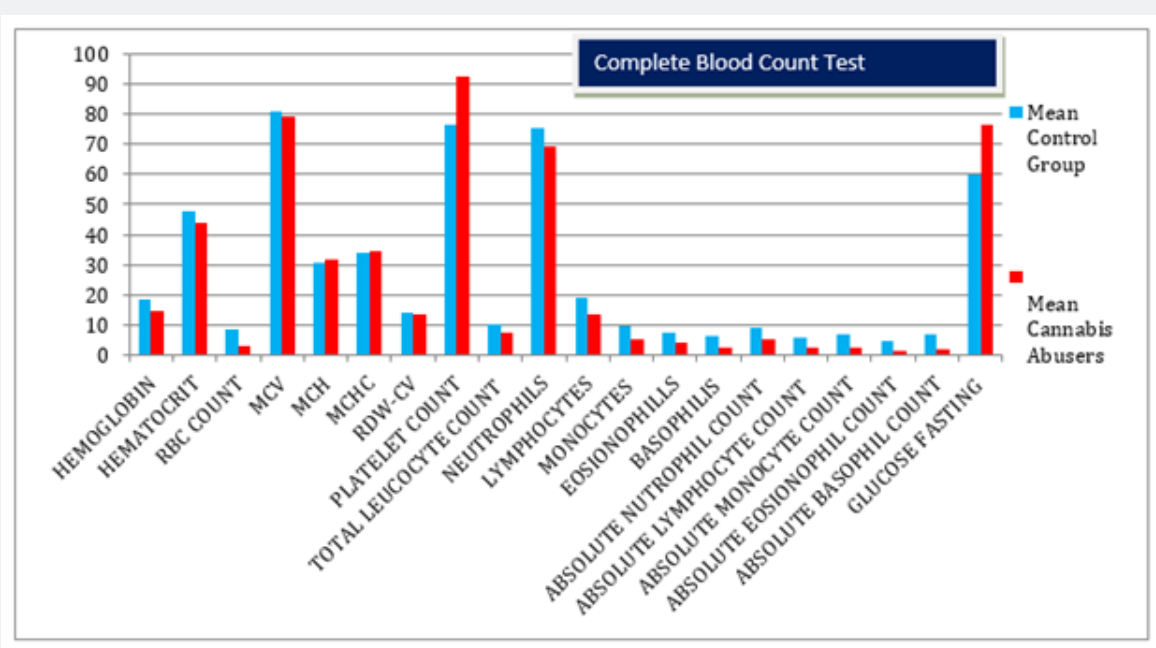

Figure 1

\section{Results and Discussion}

The result of the study showed that two groups significantly differed on Hemoglobin, Hematocrit, RBC count, platelet count, total Leucocyte count, Neutrophils, Lymphocytes, Monocytes, Eosionophills, Basophil, absolute Neutrophil count, absolute Lymphocytes count, absolute Monocyte count, absolute Eosionophil count, absolute Basophills and glucose fasting. While on the other hand MCV, MCH, MCHC and RDW-CV showed nonsignificant differences between cannabis abusers and control group on blood count test. Cannabis abusers showed lower scores in hemoglobin in complete blood count test $(M=14.58)$ in comparison with control group ( $\mathrm{M}=18.47)$. Chronic consumption of Cannabis showed that the RBC increased dose dependently with the packed cell volume not showing any considerable difference among the groups. Early studies in line indicated that there was increased hemoglobin content which agrees with the findings of Karimi et al. 13] and this may indicate that the consumption of high dose of cannabis sativa may improve oxygen carrying capacity in blood. However, the mechanism of action is not known. In context of hematocrit control group showed higher scores $(M=49.76)$ in accord with cannabis abusers $(M=43.56)$. In the present study cannabis abusers showed lower RBC count $(M=3.23)$ in evaluation with control group (M=8.54). The tetrahydrocannabinol THC has long term significant toxicological implications such as bone marrow suppression and disturbs the maturation of monocytes as well as erythrocytes (Karimi et al, 2007). Cannabis abusers showed lower scores in MCV $(M=79.41)$ in accord with control group ( $\mathrm{M}=80.67)$. In context of MCH cannabis abusers showed lower scores $(M=31.92)$ in contrast with control group ( $M=30.41)$. Cannabis abusers showed lower score in MCHC $(M=34.37)$ in 
standpoint with control group ( $M=33.89)$. In the milieu of RDWCV the cannabis abusers showed lowers scores $(M=13.33)$ in comparison with control group (14.16). The early research in line showed significant differences in the hematological parameters between the cannabis smokers (Test) and non-smoker (control) subjects. Faster pulse rate and lower body temperatures were seen among test subjects as compared to control. The values observed for total white blood cell (TWBC), ESR and RBC were lower in test subject (smokers) than the control (non-smokers), while the values observed for ESR, $\mathrm{Hb}$, and RBC were relatively close. The mean values observed for PCV, TWBC and Hb were markedly lower in test subject than in control and could be indicative of reduced percentage of blood in the cell Nwaichi and Omorodion [14]. It is plausible that treatment with high dose of Cannabis sativa extract had a microcytic effect, while treatment with low dose of Cannabis sativa had a normocytic effect. Another index for diagnosing anemia is mean corpuscular hemoglobin (MCH) and mean corpuscular hemoglobin concentration (MCHC) Archibong et al. [15]. MCH showed no differences between the control and cannabis sativa treated groups. The MCHC also did not show any difference between control and low dose groups, but was significantly raised in high dose group. However low MCHC is an indicator of hypochromia in early iron deficiency, and $\mathrm{MCH}$ level decreases as the hypochromia develops. It is therefore plausible that cannabis sativa contains $\mathrm{Hb}$ production enhancing factors. This may therefore prevent the likelihood of hypochromia in the Cannabis sativa treated rats Rose and Bentley [16].

Cannabis abusers showed higher scores in platelet count $(\mathrm{M}=$ 92.15) in accord with control group ( $M=76.56)$. Literature revealed that the cannabis dose dependent increase in platelet count. This is contrary to the report by Oseni et al. [17] reported a decrease in platelets count in human subjects. The disparity in results could be due to difference in species of animals used, duration of test as well as quality and quantity of Cannabis sativa used. This result however agrees with the findings of Maccarrone et al. [18]; Gautheir [19] who both found that Cannabis sativa consumption leads to platelet activation. The increased platelet count is probably a contributory factor in the thrombogenic potential and its implication in cardiovascular shock and myocardial infarction Mean corpuscular volume (MCV) which is the average volume of a single RBC showed a significant reduction in the high dose group compared to control and low dose groups. In patients with anaemia, MCV measurement allows for classification as microcytic (MCV below normal range), normocytic (MCV within normal range) or macrocytic (MCV above normal range) Randal et al. [20] In the perspective of total Leucocyte count cannabis abusers showed lower scores $(M=7.54)$ in comparison with control group $(\mathrm{M}=10.32)$. In the context of Neutrophils the cannabis abusers showed lower scores $(M=69.32)$ in perspective with control group $(M=75.24)$. In the context of Lymphocytes the control group showed higher scores $(M=19.33)$ in accord with cannabis abusers $(\mathrm{M}=13.33)$. The exposure to cannabis sativa using different routes can result in different effects. The total white cells count decreased significantly in all treated rats and that was due to the significant reduction of the neutrophils and lymphocytes percentages. The reduction of the neutrophils in the addicted smokers was not significant but with significant increase in the lymphocytes count Mukhtar \& Elbagir [21]. The activation of CB2, cannabinoid 2 receptor reduced ischemic injury this action involved the reduction of the number of neutrophils in the ischemic brain of experimental mice Murikinati et al. [22].

In the back ground of Monocytes the cannabis abusers showed lower scores $(M=5.32)$ in relation with control group ( $M=9.43)$. In the context of Eosionophills the cannabis abusers showed lower scores $(M=3.92)$ in perspective of control group $(M=7.32)$. In the frame work of Basophil the control group showed higher scores $(M=6.43)$ in deal with cannabis abusers $(M=2.77)$. Early research in line showed resembles with present study and indicated that there was a decrease in total white blood cells count in the group fed low and high doses of cannabis sativa when compared with control. This may be one of the reasons Cannabis sativa is used in anti-inflammatory conditions (Russo, 2001). In the context of absolute Neutrophil count the cannabis abusers showed lower scores $(M=5.22)$ in relation with control group ( $M=8.98)$. In the back ground of absolute Lymphocytes count the cannabis showed lower scores $(\mathrm{M}=2.56)$ in accord with control group). In the line of absolute Monocytes count the cannabis abusers showed lower scores $(M=2.38)$ in the harmony with control group $(M=6.78)$. In the perspective of absolute Eosionophil count the cannabis abusers showed lower scores $(M=1.17)$ in the milieu of control group ( $\mathrm{M}=4.77)$. In the frame work of absolute Basophil the cannabis abusers showed lower scores $(M=2.03)$ in reference with control group ( $\mathrm{M}=7.01)$. Earlier research indicated that cannabis sativa may lead to thromboembolism, production of immature monocytes, reduced white blood cell count and by implication reduced body defense mechanism, and it may improve RBC count with no concomitant increase in PCV but with improved $\mathrm{Hb}$ which is also shown in the high MCHC at high volume content and therefore an improved oxygen carrying capacity. It may therefore be recommended that individuals with anemia or immune complications should not use Cannabis sativa in their food preparation on regular basis Obembe et al. [23]. In the glucose fasting parameter of complete blood count cannabis abusers showed higher scores $(M=76.53)$ in concurrence with control group $(M=59.71)$. Literature revealed that there were signifi $\neg$ cant increases in fasting blood glucose and triglycerides and a decrease in high-density lipoprotein cholesterol for the cannabis negative group, with no significant changes in the cannabis positive group. Rates of metabolic syn $\neg$ drome did not differ significantly between groups Scheffler et al. [24].

\section{Conclusion}

Cannabis abuse fabricate changes in hematological indices such as in Hemoglobin, Hematocrit, RBC, MCV, MCH, MCHC, RDW-CV, Platelets, Leucocytes, Neutrophils, Lymphocytes, 
Monocytes, Eosionophil, basophil, absolute Neutrophils, absolute Lymphocytes, absolute Monocytes, absolute Eosionophills and Glucose fasting. These changes cause bone marrow suppression, thromboembolism, and hypochromia neutropenia, neutrophilic, leukocytosis, lymphocytopenia, lemphocytic leukocytosis, hypothyroidism, cushing syndrome, sepsis, asthama, allergic rhinitis, attropic dermatitis, leukemia, hereditary sperocytosis, hemolatic anemia and reduced body defense mechanism [25,26].

\section{Acknowledgement}

The author appreciates all those who participated in the study and helped to facilitate the research process.

\section{References}

1. Ebuehi OAT, Akinwande AI, Famuyiwa 00, Adebayo OA, Uzodinma EO (2005) Effect of Marijuana Smoking on Blood Chemistry and Serum Biogenic Amines Concentrations in Humans. J Health Biomed Sci 4(1): 20-24.

2. British Medical Association (BMA) (1997) Therapeutic uses of Cannabis. Harwood Academic, London, p. 66.

3. Baggio S, Deline S, Studer J, MohlerKuo, M Daeppen, JB Gmel G (2014) Routes of administration of cannabis used for nonmedical purposes and associations with patterns of drug use. J Adolesc Health 54(2): 235-240.

4. Azorlosa JL, Greenwald MK, Stitzer ML (1995) Marijuana smoking: Effects of varying puff volume and breath hold duration. J Pharmacol Exp Ther 272(2): 560-569.

5. Azorlosa JL, Heishman SJ, Stitzer ML, Mahaffey JM (1992) Marijuana smoking: Effect of varying delta-9-tetrahydrocannabinol content and number of puffs. J Pharmacol Exp Ther 261(1): 114-122.

6. Tashkin DP, Roth MD, Thadani PV (1999) Pulmonary Pathophysiology and Immune consequences of smoked substance abuse, FASEB Summer Research Conference, Copper Mountain Resort, USA Research Conference, Copper Mountain Resort, USA.

7. British Lung Foundation (BLF) (2012) The impact of Cannabis on your lungs. BLF Report.

8. Sarafian TA, Kouyoumjian S, Hoshaghideh F, Tashkin DP, Roth MD (2003) $\Delta$ 9-Tetrahydrocannabinol disrupts mitochondrial function and cell energetics. Am J Physiol Lung Cell Mol Physiol 284: L298-306.

9. Moir D, Rickert WS, Levasseur G, Larose Y, Maertens R et al. (2008) Comparison of mainstream and side stream marijuana and tobacco cigarette smoke produced under two machine smoking conditions. Chem Res Toxicol 21(2): 494-502.

10. Vogeser M, Hauer D, Azad SC, Huber E, Storr M et al. (2006) The release of anandamide from blood cells. Clin Chem Lab Med ,44 (4): 488-491.

11. Mittleman MA, Lewis RA, Maclure M, Sherwood JB, Muller JE (2001) Triggering myocardial infarction by marijuana. Circulation 103: 28052809.

12. Rodondi N, Pletcher MJ, Liu K, Hulley SB, Sidney S (2006) Marijuana use, diet, body mass index, and cardiovascular risk factors (from the CARDIA study). Am J Cardiol 98(4): 478-484.
13. Aronow WS, Cassidy J (1974) Effects of marijuana and placebo marijuana smoking on angina pectoris, New Engl J Med 291(2): 65-67, 2171-2178.

14. Karimi I, Hayatghaibi H, Yousef J, Saberivand A, Zavarcli S (2007) The effect of Cannabis sativa L (hemp seed) on haematological parameter in guinea pigs. Cardiovascular and Haematological Indices. Drug Targets 7(4): 288-290.

15. Nwaichi EO, Omorodion FO (2015) Evaluation of Effect of Cannabis Smoking on the Hematological Properties of Selected Adult Male Students Smokers. Int J Anat Appl Physiol 1(1): 1-5.

16. Archibong NA, Ofem EO, Nna VU, Bision EM, Johnson JI, et al. (2014) Changes in haematological parameters following the administration of crude extract from tympanotonus fuscatus (periwinkle) in rats. Australian Journal of Basic and Applied Sciences 8(10): 586-591.

17. Rose DW, Bentley SA (1986) Evaluation of an automated haematology system (Technico HI) Archives of Pathology and Laboratory Medicine 110(9): 803-808.

18. Oseni BS, Togun VA, Taiwo (2006) Effect of Marijuana smoking on some haematological parameters of smokers. World Journal of Medical Sciences 1(2):82-85.

19. Maccarrone M, Bari M, Menichelli A, Me I PD, Finazzi A (1999) Anandamide activates human platelets through a pathway independent of the arachidonate cascade. FEBS Let $448: 277-282$.

20. Gautheir M (2005) Endothelium derived 2 arachiglonylorolL an intermediate in vasodilatory eicosanoid release in bovine coronary arteries. Am J Physiol 288(3): 1344-1351.

21. Mukhtar AH, Elbagir NM (2011) Effect of Cannabis sativa on Hematological Indices in Rats and Men. Pakistan Journal of Nutrition 10(4): 313-316.

22. Murikinati S, Jüttler E, Keinert T, Ridder DA, Muhammad S, et al. (2010) Activation of cannabinoid 2 receptors protects against cerebral ischemia by inhibiting neutrophil recruitment. The FASEB J 24(3): 788-798.

23. Obembe AO, Omini1 GC, Okon UA, Okpo ene AI, Ikpi DE (2015) Hematological and immunological effect of cannabis sativa on albino wistar rats. British Journal of Medicine \& Medical Research 7(1): 5260.

24. Scheffler F, Kilian S, Chiliza B, Asmal L, Phahladira L, et al. (2018) Effects of cannabis use on body mass, fasting glucose and lipids during. The first 12 months of treatment in schizophrenia spectrum disorders Abstracts for the Sixth Biennial SIRS Conference.

25. Deusch E, Kress HG, Kfraft B , Kozek Langenecker SA (2004) The procoagulatory effects of delta-9-tetrahydrocannabinol in human platelets. Anesth Analg 99(4): 1127-1130.

26. Russo M (2001) Cannabis and cannabis extracts: greater than the sum of their parts. Cannabis therapeutics in HIV/AIDS. Huberman E. Nature science, Harworth Press, pp. 103-132. 
(C) (1) Commons Attribution 4.0 License BY DOI: 10.19080/JOJNHC.2018.08.555745

\section{Your next submission with Juniper Publishers will reach you the below assets}

- Quality Editorial service

- Swift Peer Review

- Reprints availability

- E-prints Service

- Manuscript Podcast for convenient understanding

- Global attainment for your research

- Manuscript accessibility in different formats

(Pdf, E-pub, Full Text, Audio)

- Unceasing customer service

Track the below URL for one-step submission https://juniperpublishers.com/online-submission.php 